\title{
The effect of phosphorus on nitrogen retention in lakes
}

\author{
T. Frisk, Ä. Bilaletdin \& H. Kaipainen \\ Pirkanmaa Regional Environment Centre, Finland
}

\begin{abstract}
A hypothesis has been presented that nitrogen retention in lakes has become less efficient at the same time as phosphorus concentrations have decreased due to high phosphorus reduction in wastewater treatment. This might have led to higher loading of nitrogen into the Baltic Sea where nitrogen is considered to be the minimum nutrient. The hypothesis was tested using the mass balance modelling approach. Oligotrophic, mesotrophic and moderately eutrophic lakes situated in Finland and Sweden were used in the study. The combined approach of the classical mass balance model of Vollenweider and the statistical sedimentation model of Bachmann was used. At first the model was tested for nitrogen without any impact of phosphorus and it was concluded that this modelling approach is reasonable to study the hypothesis. If phosphorus concentration or retention affects nitrogen retention a better fit for the model of nitrogen retention can be gained when a function of phosphorus input or concentration is included in the nitrogen model of Bachmann. The results indicate that inclusion of phosphorus does not improve the fit of the model and thus it can be concluded that phosphorus can only be a minor factor in regulating nitrogen retention, at least in lakes which are not hypereutrophic.
\end{abstract}

Keywords: nitrogen, phosphorus, retention, lakes, mass balance, models.

\section{Introduction}

In the process of eutrophication phosphorus and nitrogen are the most important nutrients and regulating factors. In lacustrine environments phosphorus loading is usually the main factor regulating eutrophication whereas in marine environments nitrogen is more important. In brackish waters such as the Baltic Sea both of these nutrients may be limiting algal growth. However, it has been 
found that nitrogen is the most important limiting nutrient in the Baltic Sea [1] and therefore particular attention has been paid to reduction of nitrogen loading into the Baltic Sea.

Because the impact of phosphorus on the trophic status is so clear wastewaters are treated so effectively that the reduction percentage of phosphorus is higher than 90, up to 98. Today agricultural contribution to nutrient loading from the catchments is dominating compared to domestic wastewaters from cities and other communities. Fortunately, the whole nutrient flow from the catchment does not enter the Baltic Sea because the percentage of lakes in the drainage basins is great at least in Finland, Sweden and part of Russia, and the detention times of the lakes are relatively long. Thus retention of phosphorus and nitrogen reduces nutrient flows to great extent.

In Sweden, Stålnacke et al. [2] found that an upward trend in nitrogen flows has taken place in the mid and late 1970s, i.e. at the end of the period during which phosphorus removal had been introduced at practically all municipal wastewater treatment plants in Sweden. Because phosphorus is the main limiting factor in algal growth it can be assumed that the lakes became less eutrophic along with the reduction of phosphorus loading. Thus Stålnacke et al. [2] presented a hypothesis that nitrogen retention has decreased along with the reduced phosphorus loading and degree of eutrophy. A similar hypothesis was earlier presented by Ahl [3] for Lake Vänern.

Retention of a substance can be defined as the difference between input and output of the substance. In this study long-term average values, referring to steady state modelling, are only considered. For phosphorus, retention is thus the same as net sedimentation, i.e. the difference between gross sedimentation and the release from the sediment. For nitrogen, the situation is more complicated because in addition to sedimentation and release from the sediment also denitrification and nitrogen fixation must be included. Thus retention of nitrogen is the same as the sum of net sedimentation and denitrification subtracted by nitrogen fixation.

In this study the effect of phosphorus on nitrogen retention in lakes was studied using mass balance modelling approach. The central idea was to find out if the fit of nitrogen balance model can be improved by adding variables related to phosphorus balance into the equation describing nitrogen balance. The study was part of the NUTRIBA project within the Baltic Sea Research Programme of the Academy of Finland (BIREME).

\section{The modelling approach}

As the starting point the classical first order CSTR mass balance model of Vollenweider $[4,5]$ was used. At steady state the basic equation can be given as

$$
I-Q c-\sigma c V=0
$$

where

$I=\operatorname{input}\left(\mathrm{M} \mathrm{T}^{-1}\right)$ 
$Q=$ discharge $\left(\mathrm{L}^{3} \mathrm{~T}^{-1}\right)$

$\sigma=$ first order retention coefficient $\left(\mathrm{T}^{-1}\right)$

$c=$ concentration in the lake $\left(\mathrm{M} \mathrm{L}^{-3}\right)$

$V=$ volume of the lake $\left(\mathrm{L}^{3}\right)$

According to the CSTR principle water quality is uniform in the lake and thus the second term on the left-hand side of eqn. (1) represents the output through the outlet of the lake. When long-term average values are considered this description is justified. The third term represents retention.

It was already found by Vollenweider [4, 5] that $\sigma$ is not a universal constant but varies from lake to lake. Canfield and Bachmann [6] have presented a statistical model by means of which the first order reaction coefficient can be calculated for phosphorus. Bachmann [7] has presented a similar model for nitrogen:

$$
\sigma=a_{n}\left(\frac{I}{V}\right)^{b}
$$

where

$\sigma=$ first order retention coefficient for nitrogen $\left(a^{-1}\right)$

$I=$ input of nitrogen $\left(\mathrm{mg} \mathrm{a}^{-1}\right)$

$V=$ volume of the lake $\left(\mathrm{m}^{3}\right)$

$a_{n}=0.0159$

$b=0.594$

Concentration of nitrogen (c) can be calculated from eqn. (1) as follows:

$$
c=\frac{I}{Q+\sigma V}
$$

Only total input into the lake, discharge and volume of the lake are needed. The value of $\sigma$ is received from eqn. (2).

The "empirical" value of $\sigma$ can be calculated from eqn. (3) on the basis of input, discharge, volume and concentration:

$$
\sigma=\frac{I-Q c}{c V}
$$

If the retention model described the retention process completely the $\sigma$ values calculated by eqn. (4) would be equal to the values calculated by eqn. (2). In this case the values of the parameter $a_{n}$ would be constant and not varying with lakes.

If retention of nitrogen is dependent on phosphorus it can be assumed that the predicting capacity on the nitrogen retention model can be improved by including a function of phosphorus into the model. Then necessarily coefficient 
$a_{n}$ in eqn (2) would be dependent on phosphorus retention. Phosphorus retention is according to Canfield and Bachmann [6] and many other authors [7-10] dependent on phosphorus input into the lake and it can also be described as a function of phosphorus concentration in the lake $[4,5,11,12]$. Two possibilities to take into account the impact of phosphorus were studied:

$$
\begin{gathered}
a_{n}=f\left(\frac{I_{p}}{V}\right) \\
a_{n}=f\left(c_{p}\right)
\end{gathered}
$$

where

$I_{p}=$ total input of phosphorus $\left(\mathrm{mg} \mathrm{a}^{-1}\right)$

$V=$ volume of the lake $\left(\mathrm{m}^{3}\right)$

$c_{p}=$ phosphorus concentration in the lake $\left(\mathrm{mg} \mathrm{m}^{-3}\right)$

If reasonable functions of eqns. (5) and (6) can be formed their inclusion into eqn. (2), applied together with eqn. (3), will improve the predicting capacity of the nitrogen balance model and thus prove that retention of nitrogen is dependent on phosphorus. The values of the coefficient $a_{n}$ are calculated by dividing the coefficient $\sigma$ from eqn. (4) by the power function of $\mathrm{I} / \mathrm{V}$ :

where $b=0.594$.

$$
a_{n}=\frac{\sigma}{\left(\frac{I}{V}\right)^{b}}
$$

\section{Material and methods}

Two data sets were used. One set consists of Finnish lakes situated in the catchment of the river Kokemäenjoki in South-West Finland (table 1). The other data set which consists of Swedish lakes and is based on different sources and has been described by Persson [13]. Discharges were calculated by dividing the watershed areas by runoff values. Average concentrations for nitrogen and phosphorus were calculated according to the CSTR description as the ratio of substance output and discharge. Frisk et al. [10] noticed that the predictability of mass balance models for phosphorus is poor in highly eutrophic lakes. Even though main attention is paid to nitrogen modelling in this study it is also important that phosphorus modelling procedure is valid in the lakes of the study. Therefore lakes with phosphorus concentration higher than $50 \mathrm{mg} \mathrm{m}^{-3}$ were omitted from the data.

The models described in chapter 2 were applied using the Finnish and the Swedish data sets separately and also using both of the data sets together. 
Table 1: The data of the lakes in the drainage basin of the river Kokemäenjoki. $\mathrm{V}=$ volume of the lake $\left(10^{6} \mathrm{~m}^{3}\right), \mathrm{Q}=$ discharge $\left(\mathrm{m}^{3}\right.$ $\left.\mathrm{s}^{-1}\right), \mathrm{I}=$ total nitrogen input $\left(10^{9} \mathrm{mg} \mathrm{a}^{-1}\right), \mathrm{I}_{\mathrm{p}}=$ total phosphorus input $\left(10^{9} \mathrm{mg} \mathrm{a}^{-1}\right), \mathrm{c}=$ nitrogen concentration $\left(\mathrm{mg} \mathrm{m}^{-3}\right), \mathrm{c}_{\mathrm{p}}=$ phosphorus concentration $\left(\mathrm{mg} \mathrm{m}^{-3}\right)$.

\begin{tabular}{|l|r|r|r|r|r|r|}
\hline Lake & $\mathrm{V}$ & $\mathrm{Q}$ & $\mathrm{I}$ & $\mathrm{I}_{\mathrm{p}}$ & $\mathrm{c}$ & $\mathrm{c}_{\mathrm{p}}$ \\
\hline Kuohijärvi & 347 & 6.20 & 106 & 3.5 & 385 & 5.7 \\
\hline Kukkia-itä & 97 & 6.66 & 125 & 2.6 & 358 & 9.1 \\
\hline Kukkia-länsi & 163 & 7.54 & 107 & 3.0 & 329 & 9.6 \\
\hline Pyhäjärvi & 104 & 2.89 & 112 & 2.9 & 577 & 12 \\
\hline Parkanonjärvi & 35 & 6.94 & 233 & 10 & 853 & 31 \\
\hline Koveslahti & 50 & 3.37 & 128 & 5.8 & 841 & 38 \\
\hline Heittolanlahti & 21 & 12.11 & 319 & 13 & 700 & 31 \\
\hline Kelminselkä & 64 & 4.56 & 247 & 9.9 & 1245 & 42 \\
\hline Viljakkalanselkä & 45 & 0.49 & 27 & 1.0 & 713 & 21 \\
\hline Kyrösjärvi1 & 700 & 25.74 & 731 & 29 & 799 & 24 \\
\hline Kyrösjärvi2 & 116 & 26.27 & 681 & 21 & 777 & 22 \\
\hline Iso-Roine & 247 & 13.14 & 189 & 4.9 & 391 & 11.8 \\
\hline Hauhonselkä & 89 & 2.26 & 102 & 4.0 & 692 & 26.8 \\
\hline Ilmoilanselkä & 89 & 18.42 & 264 & 8.0 & 434 & 17 \\
\hline Uuraslahti & 7 & 0.69 & 34 & 1.4 & 1227 & 50 \\
\hline Nerkoojärvi & 56 & 1.10 & 44 & 1.9 & 590 & 21 \\
\hline
\end{tabular}

\section{Results}

The correspondence between observed and calculated nitrogen concentrations was good in the Finnish data set with a correlation coefficient of 0.939 $(p<0.0001)$ (fig. 1). The correspondence was not as good in the Swedish data set but, however, the correlation coefficient was $0.624(\mathrm{p}<0.001)$ (fig. 1). In the whole data the correlation coefficient was $0.646(\mathrm{p}<0.0001)$.

In some lakes there were considerable differences between observed and calculated nitrogen concentrations. It was studied if the fit of the model could be improved by including phosphorus concentration or input in the model. The fit of the model could be improved if coefficient $a_{n}$ in eqn. (2) could be described as dependent on phosphorus. In Finnish lakes $a_{n}$ is almost constant (fig. 2) which indicates the fact that the basic model for nitrogen can be well used without phosphorus. $a_{n}$ does not seem to be dependent on phosphorus concentration. In Swedish lakes the situation is a little different because there is more variation (fig. 2). However, there is no clear dependence between phosphorus concentration and $a_{n}$ and thus no reasonable function $f\left(c_{p}\right)$ can be formed. Eqn, (5) cannot improve the fit of the model. The non-significant correlation coefficients are $r=-0.309(p=0.244)$ for Finnish lakes, $r=0.097(p=0.593)$ for Swedish lakes and $\mathrm{r}=0.070(\mathrm{p}=0.633)$ for the whole data. 
Table 2: $\quad$ The data of the Swedish lakes [13]. $\mathrm{V}=$ volume of the lake $\left(10^{6}\right.$ $\left.\mathrm{m}^{3}\right), \mathrm{Q}=$ discharge $\left(\mathrm{m}^{3} \mathrm{~s}^{-1}\right), \mathrm{I}=$ total nitrogen input $\left(10^{9} \mathrm{mg} \mathrm{a}^{-1}\right), \mathrm{I}_{\mathrm{p}}$ $=$ total phosphorus input $\left(10^{9} \mathrm{mg} \mathrm{a}^{-1}\right), \mathrm{c}=$ nitrogen concentration $\left(\mathrm{mg} \mathrm{m}^{-3}\right), \mathrm{c}_{\mathrm{p}}=$ phosphorus concentration $\left(\mathrm{mg} \mathrm{m}^{-3}\right)$.

\begin{tabular}{|c|c|c|c|c|c|c|}
\hline Lake & $\mathrm{V}$ & Q & I & $\mathrm{I}_{\mathrm{p}}$ & $\mathrm{c}$ & $\mathrm{c}_{\mathrm{p}}$ \\
\hline Magnusjaure+N & 0.03 & 0.0010 & 0.041 & 0.0001 & 400 & 4 \\
\hline Gårdsjön & 1.5 & 0.0169 & 0.732 & 0.0062 & 400 & 5 \\
\hline Vättern & 74000 & 36.02 & 3192 & 74 & 740 & 7 \\
\hline Stugsjön & 0.02 & 0.0009 & 0.013 & 0.0006 & 197 & 7 \\
\hline Aspen & 79.6 & 11.14 & 613 & 10 & 956 & 10 \\
\hline Örträsket & 160 & 17.39 & 200 & 7.0 & 300 & 11 \\
\hline Kalvsjön & 44.9 & 3.73 & 115 & 4.0 & 500 & 12 \\
\hline Fegen & 181.7 & 1.32 & 63 & 2.4 & 420 & 14 \\
\hline Mjörn & 850 & 8.43 & 854 & 30 & 950 & 14 \\
\hline Bolmen & 1070 & 13.12 & 4399 & 11 & 522 & 14 \\
\hline Ivösjön & 558.29 & 7.97 & 379 & 6.8 & 800 & 14 \\
\hline Botjärn & 0.32 & 0.0235 & 0.36 & 0.011 & 420 & 14 \\
\hline Boren 2 & 170 & 51.50 & 493 & 11 & 440 & 15 \\
\hline Väsman & 410 & 9.19 & 185 & 7.7 & 480 & 15 \\
\hline Vidöstern & 211.23 & 10.22 & 538 & 14 & 553 & 17 \\
\hline Erken & 214 & 0.94 & 47 & 1.4 & 770 & 18 \\
\hline Södra Barken & 63 & 17.53 & 333 & 12 & 529 & 18 \\
\hline Åsunden & 293 & 4.48 & 350 & 5.3 & 1130 & 20 \\
\hline Boren 1 & 170 & 51.50 & 652 & 50 & 450 & 26 \\
\hline Mälaren C & 8450 & 94.78 & 6905 & 290 & 400 & 29 \\
\hline Roxen & 748 & 105.86 & 3201 & 75 & 700 & 30 \\
\hline Hymenjaure+P & 0.03 & 0.0017 & 0.005 & 0.006 & 200 & 30 \\
\hline Hornborgasjön & 25 & 4.68 & 644 & 7.6 & 1600 & 30 \\
\hline Oppmannasjön & 49.65 & 0.73 & 103 & 1.1 & 1000 & 32 \\
\hline Gåran & 0.23 & 0.21 & 10 & 0.26 & 810 & 40 \\
\hline Gunillajaure $+\mathrm{N}+\mathrm{P}$ & 0.14 & 0.0016 & 0.13 & 0.01 & 130 & 40 \\
\hline Glan & 470 & 119.03 & 3546 & 135 & 650 & 45 \\
\hline V. Storsjön & 181.5 & 9.25 & 204 & 9.0 & 470 & 45 \\
\hline Ö. Storsjön & 89.35 & 17.10 & 455 & 18 & 700 & 45 \\
\hline Hjälmaren & 2893 & 26.72 & 2657 & 67 & 798 & 46 \\
\hline Mälaren A & 210 & 69.14 & 3607 & 154 & 600 & 48 \\
\hline Ralången & 13.41 & 4.76 & 170 & 3.7 & 1200 & 50 \\
\hline Tåkern & 35 & 2.75 & 207 & 7.2 & 2000 & 50 \\
\hline
\end{tabular}




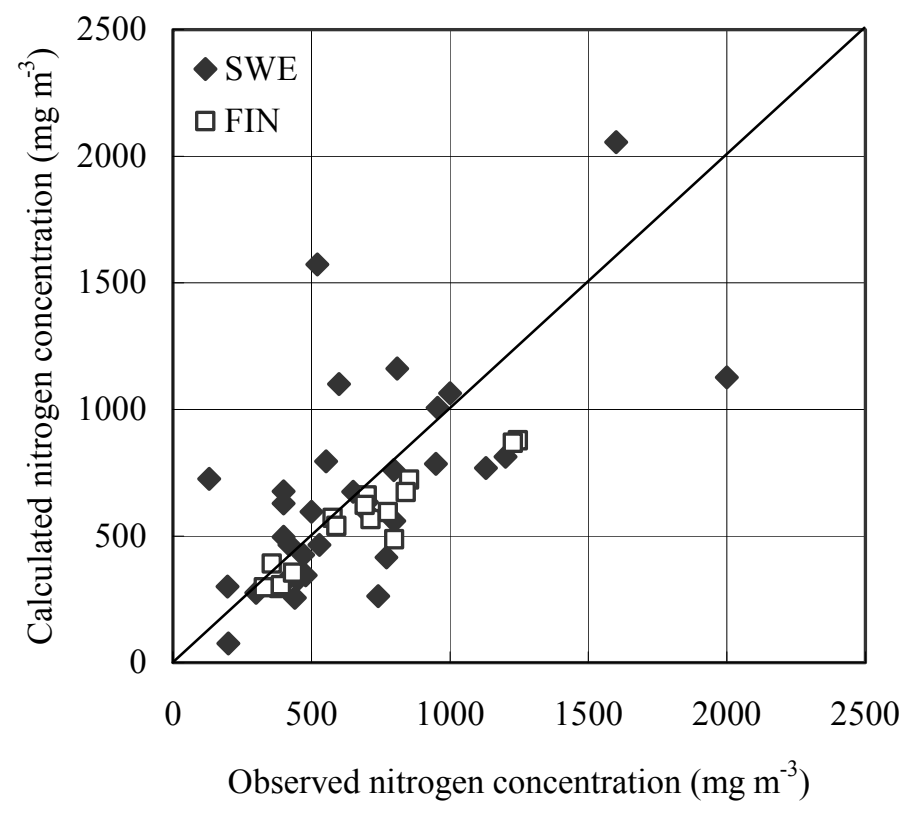

Figure 1: Observed and calculated (eqns. 3 and 2) nitrogen concentrations. $\square=$ Finnish lakes, $\diamond=$ Swedish lakes.

The situation is still worse when $a_{n}$ is plotted against I/V. There is no clear dependence in the Finnish nor the Swedish data sets (fig. 3). The non-significant correlation coefficients are $r=-0.108(\mathrm{p}=0.692)$ for Finnish lakes, $r=0.162$ $(p=0.369)$ for Swedish lakes and $r=0.148(p=0.310)$ for the whole data.

Thus inclusion of phosphorus does not improve the predicting capacity of the nitrogen balance model and nitrogen retention does not seem to be dependent on phosphorus in the data sets of the study which represent a large variety of lakes from oligotrophy to moderate eutrophy.

\section{Discussion}

The idea that nitrogen retention is dependent on phosphorus in lakes could be theoretically expected. In lakes in which phosphorus concentrations are high also primary production is high. Thus also sedimentation of phytoplankton and nutrients is high. Nitrogen retention may be found to be dependent on phosphorus input or concentration in many cases because phosphorus and nitrogen loadings are often strongly correlated. In the data of this study the correlation coefficient between nitrogen loading and phosphorus loading is = $0.884(\mathrm{p}<0.0001)$ and nitrogen retention and phosphorus retention $=0.775$ $(p<0.0001)$. These correlation coefficients would be still much higher if one lake 
were omitted from the data. Thus it is clear that nitrogen retention can be at least to a certain extent predicted by means on phosphorus loading but it does not prove that phosphorus per se is a key factor in this process.

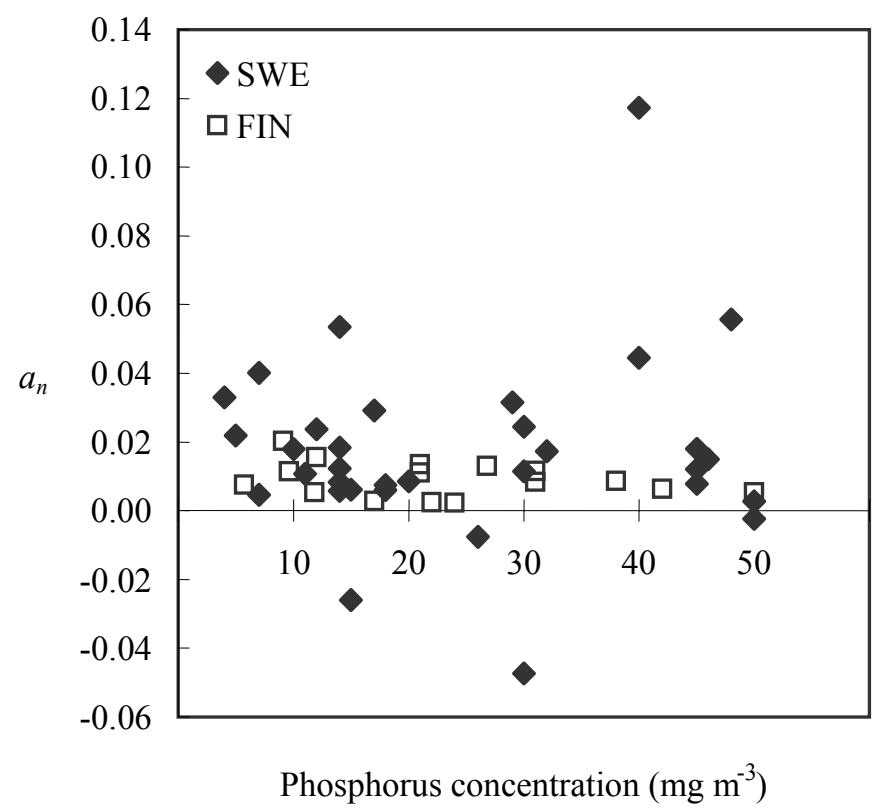

Figure 2: The dependence of sedimentation constant $a_{n}$ on phosphorus concentration. $\square=$ Finnish lakes, $\downarrow=$ Swedish lakes.

In this study highly eutrophic lakes with total phosphorus concentration higher than $50 \mathrm{mg} \mathrm{m}^{-3}$ were not considered. It is possible that in hypereutrophic lakes reduction of phosphorus loading decreases retention of nitrogen. Retention percentage of phosphorus is low in this kind of lakes and the generally applied statistical phosphorus retention formulae do not give reliable results [10]. The large lakes in the catchment of the Baltic Sea which cause most of the nutrient retention are usually oligotrophic or mesotrophic or only moderately eutrophic and the main interest of this study was in this kind of lakes in which no direct impact on phosphorus on nitrogen retention was found.

The retention mechanisms are different for nitrogen than for phosphorus. For nitrogen, sedimentation is not necessarily the most important factor but denitrification may dominate. On the other hand nitrogen fixation reduces retention because it is not included in the input term. Nitrogen fixation is particularly high in lakes with low nitrogen/phosphorus ratio, due to nitrogen fixing cyanobacteria. In some lakes the retention constant $a_{n}$ is negative which could indicate effective nitrogen fixation. The nitrogen/phosphorus ratio varied in these lakes between 7 and 29 while the mean value of the whole data was 36 . Denitrification is in principle an anaerobic process. However, total anoxia is not 
required but local low redox potential is sufficient. In highly eutrophic lakes contribution of denitrification to nitrogen retention is high. In Lake Enäjärvi Kettunen [14] found it to be about 90\%. Also Persson [13] reported high shares of denitrification in nitrogen retention in large Swedish lakes.

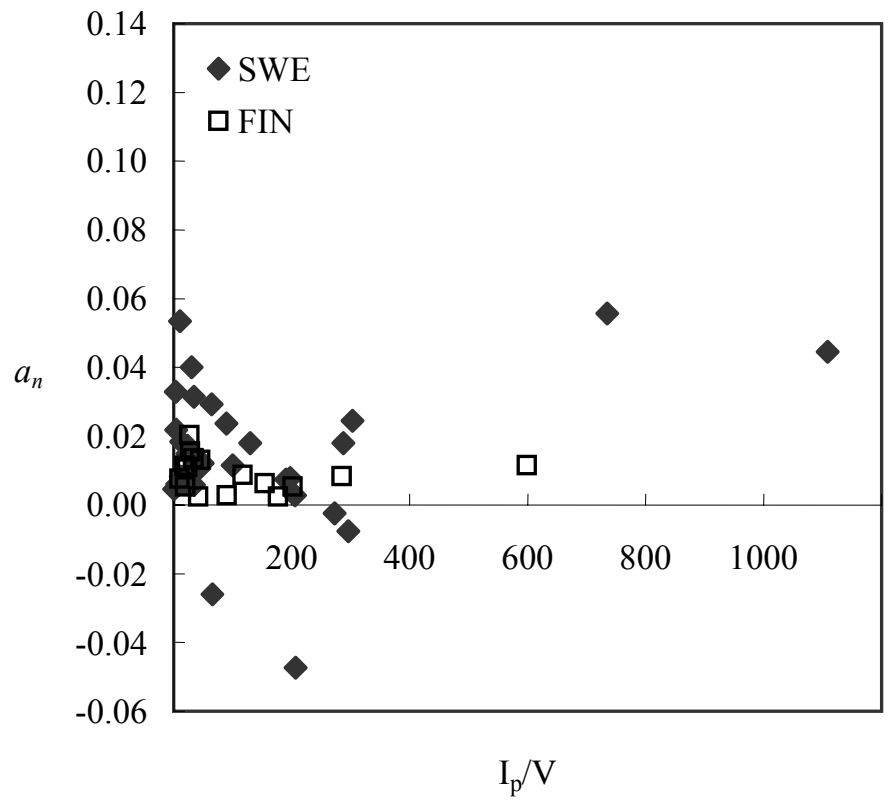

Figure 3: The dependence of sedimentation constant $a_{n}$ on the ratio of phosphorus input and the volume of the lake $\left(\mathrm{I}_{\mathrm{p}} / \mathrm{V}\right)$. $\square=$ Finnish lakes, $=$ Swedish lakes.

As a concluding remark it can be stated that no indication was found about the impact of phosphorus input or concentration on nitrogen retention in lakes. So it seems that the water protection strategy with efficient phosphorus removal has not led to higher nitrogen loading to the Baltic Sea.

\section{References}

[1] Tamminen, T. Eutrophication and the Baltic Sea: Studies on phytoplankton, bacterioplankton, and pelagic nutrient cycles. $\mathrm{PhD}$ thesis. Univ. of Helsinki, Dept. Environmental Conservation, 1990.

[2] Stålnacke, P., Grimvall, A., Sundblad, K. \& Wilander, A. trends in nitrogen transport in Swedish rivers. Environmental Monitoring, 59, pp. 47-72, 1999.

[3] Ahl, T. Eutrofiering av Västerhavet - mekansimer, orsaker och åtgärder. Näringsbelastning på Västerhavet - källfördelning. Kungliga Skogs- och Lantbruksakademins Tidskrift, 129, pp. 135-143, 1990 (in Swedish). 
[4] Vollenweider, R.A. Möglickeiten und Grenzen elementarer Modelle der Stoffbilanz von Seen. Arch. Hydrobiol., 66(1), pp. 1-36, 1969.

[5] Vollenweider, R.A. Input-output models with special reference to the phosphorus loading concept in limnology. Schweiz. Z. Hydrol., 37(1), pp.53-84, 1975 (in German).

[6] Canfield, D.E. Jr. \& Bachmann, R.W. Prediction of total phosphorus concentrations, chlorophyll $\mathrm{a}$, and Secchi depth in natural and artificial lakes. Can. J. Fish. Aquat. Sci., 38(4), pp. 414-423, 1981.

[7] Dillon, P.J. \& Rigler, F.H. A simple method for predicting the capacity of a lake for development based on lake trophic status. J. Fish. Res. Board. Can. 32(9), pp. 1519-1531, 1975.

[8] Lappalainen, K.M, Kehitysarviot eri kuormitusvaihtoehdoilla: Kallaveden reitti ja Haukivesi. Nat. Board. Wat. Rep. 59, Helsinki, Finland, 1974 (in Finnish).

[9] Lappalainen, K.M. Phosphorus loading capacity of lakes and a mathematical model for water quality prognoses. Eutrofiering. Tionde nordiska symposiet om vattenforskning, Værløse 20 - 22 maj 1974. Nordforsk Miljövårdssekretariatet. Publikation 1975(1), pp. 425-441, 1975.

[10] Frisk, T., Niemi, J.S. \& Kinnunen, K.A.I. Comparison of statistical phosphorus retention models. Ecological Modelling 12(1) pp. 11-27, 1981.

[11] Frisk, T. Development of mass balance models for lakes. Publ. Wat Env. Res. Inst. 5, Helsinki, Finland, 1989.

[12] Frisk, T. Mass balance models for elongated lakes. Hydrobiologia 243/244, pp. 341-349. 1992.

[13] Persson, G. Nitrogen retention in lakes in Sweden; a review. Department of Environmental Assessment, Swedish university of Agricultural Sciences, Rapport 2003:19, 2003.

[14] Kettunen, J. Ravinteiden kierto matalassa eutrofisessa järvessä sovelluskohteena Vihdin Enäjärvi. Department of Water Technology, Helsinki University of Technology, Espoo, Finland, 1980 (in Finnish). 